\title{
ANALYSIS STUDENTS' CRITICAL THINKING SKILLS IN SOLVING PROBLEMS IN TERMS OF COGNITIVE STYLE
}

\author{
*Nisa Ul Amini' ${ }^{1}$ Maimunah ${ }^{2}$, Yenita Roza $^{3}$ \\ ${ }^{1,2,3}$ Program Pascasarjana Pendidikan Matematika \\ Fakultas Keguruan dan Ilmu Pendidikan Universitas Riau \\ ${ }^{1}$ nisa.u16933@grad.unri.ac.id (CA) \\ ²maimunah@lecturer.unri.ac.id
}

\begin{abstract}
Abstrak
Tujuan dari penelitian ini adalah untuk menganalisis kemampuan berpikir kritis siswa dalam menyelesaikan masalah yang ditinjau dari gaya kognitif. Penelitian ini termasuk dalam Penelitian Kualitatif dengan metode deskriptif kualitatif. Subjek penelitian ini adalah siswa kelas VIII MTSN 3 Rokan Hulu. Teknik pengumpulan data dalam penelitian ini menggunakan tes GEFT (Group Embredded Figure Test) yang dikembangkan oleh Witkin dan tes kemampuan berpikir kritis berupa soal uraian. Teknik analisis data dilakukan dengan reduksi data, pemaparan data, analisis data pada kedua kelompok subjek dan penarikan kesimpulan. Analisis kemampuan berpikir kritis dalam penelitian ini menggunakan indikator dari Ennis yaitu merumuskan strategi, memberikan alasan, dan menyimpulkan. Penelitian ini menunjukkan perbedaan gaya kognitif siswa mempengaruhi kemampuan berpikir kritis siswa. Hasil penelitian menunjukkan bahwa siswa dengan gaya kognitif field independent memiliki kemampuan berpikir kritis lebih baik daripada siswa dengan gaya kognitif field dependent.
\end{abstract}

Kata Kunci : Berpikir Kritis, Gaya Kognitif

\begin{abstract}
The purpose of this study is to analyze students' critical thinking skills in solving problems in terms of cognitive style. This research is included in the Qualitative Research with descriptive qualitative methods. The subjects of this study is eighth grade students of MTSN 3 Rokan Hulu. Data collection technique of this study is used the GEFT test (Group Embredded Figure Test) that developed by Witkin and the critical thinking ability test is a description item. Data analysis technique is done by data reduction, data exposure, data analysis in both subject groups and drawing conclusions. Analysis of critical thinking skills in this study uses an indicator from Ennis, which is to formulate strategy, give reason, and conclude. This study shows differences in students 'cognitive style give affect to students' critical thinking skills. The results showed that students with independent field cognitive style had better critical thinking skills than students with field dependent cognitive style.
\end{abstract}

Keywords: Critical Thinking, Cognitive Style

Citation: Amini, N. U., Maimunah., dan Roza, Y. 2019. Analysis Students' Critical Thinking Skills in Solving Problems in Terms of Cognitive Style. Matematika dan Pembelajaran, 7(2), 51-69. DOI: http://dx.doi.org/10.33477/mp.v6i2z 


\section{INTRODUCTION}

Mathematics is one of the basic sciences that is developing rapidly at this time, Syahbana (2012: 46) states that mathematics as a discipline that clearly relies on thought processes is considered very good to be taught to students. It means that learning mathematics is aim to familiarize students able to think systematically, logically, critically, and creatively, specifically able to develop students' critical thinking skills. Chotimah \& Bernard (2018) said that mathematics is one of the lessons that is closely related to real life, not a few things or problems that surround us need mathematics. One of the goals to be successful in learning mathematics is the ability to think critically students in solving mathematical problems.

Natasia, Ariawan \& Sthepahani (2018) states that critical thinking is a must in efforts to solve problems, make decisions, analyze assumptions systematically, innovatively and fundamental design solution. Furthermore, Natasia, and friends also states that critical thinking can be developed through mathematics learning because mathematics has a complete and clear structure and study between concepts. According to Ennis (2011) critical thinking is a process that aims to make sensible decisions about what we believe and what we do. Students' critical thinking skills can certainly affect students learning outcomes, especially in learning mathematics, the ability to think critically mathematically is very important for every student to gain an understanding of the learning he has received. Mathematical critical thinking ability is a process of critical thinking in solving mathematical problems, although critical thinking skills are very important, but in reality these abilities have not been mastered well by Indonesian students.

According to Ennis (Sunaryo, 2013) in critical thinking there are 6 indicators, (1) Focus, is understanding the problem and determining the matter in the problem, (2) Reason, is giving reason in answering or concluding, (3) Conclusion, is estimating conclusion that will be obtained, (4) Situation, is applying the strategy / concept of knowledge that was previously owned to solve the problem in an existing situation, (5) Clarity, which presents problems or problems similar to those already existing, (6) Examination or Review, which checks the correctness of the answers. 
The survey results from 72 countries around the world in working on nonroutine questions that require high analytical, reasoning and mathematical communication skills conducted by PISA and coordinated by the OECD show the critical thinking skills of Indonesian students are low, can be seen in the following table 1 :

Table 1. Indonesian Ranking in Mathematics Subjects Based on PISA Survey

\begin{tabular}{ccc}
\hline Years & Indonesia Ranking & Countries Amount \\
\hline 2006 & 50 & 57 \\
\hline 2009 & 61 & 65 \\
\hline 2012 & 64 & 65 \\
\hline 2015 & 69 & 76 \\
\hline 2018 & 74 & 79 \\
\hline
\end{tabular}

Sumber: OECD (2019)

Table 1 shows that the ability of Indonesian students in mathematics especially in working on non-routine questions that require students to think critically is low compared to other countries, it can be seen that the ability of Indonesian students in mathematics is categorized lower than other countries. In addition to PISA, the results of the TIMSS international study also showed that Indonesian students' mathematics learning achievement was still low, in 2015 ranked 45 out of 50 countries. The results of the PISA and TIMSS show that the quality of education in Indonesia, especially in learning mathematics is still concerning compared to other countries, this showed that learning mathematics in Indonesia needs to be improved. Based on the Government's Ministry of Education and Culture No. 21 of 2016 concerning standard content of primary and secondary education, one of the competencies that will be achieved in learning mathematics is the ability to think critically.

The ability to think critically of each student is different, this can be seen from some of the results of research on students' mathematical critical thinking abilities that have been done before. Herdiman, and friends (2018) in their research concluded that students' mathematical critical thinking skills were still very low, 
the focus indicators are $88.89 \%$ of students who answered incorrectly, the indicator gave reasons are $80.56 \%$ of students who answered incorrectly, the clarity indicators are $80,56 \%$ of students answered incorrectly, as well as the review or conclusion indicators there were $77.78 \%$ of students who answered incorrectly. Research conducted by Septiana (2019) also concluded that the mathematical critical thinking ability of junior high school students on flat side space material was still very low, by looking at the average percentage value of all indicators under $50 \%$ is the indicator gave an argument of $45 \%$ indicating a small portion of students able to give his opinion in working on the problem, the indicator understands the problem $43 \%$, the indicator induces $38 \%$ and the lowest is the indicator of decision making or action $33 \%$.

Both studies show that students' mathematical critical thinking abilities are still very low and different. The difference in the ability to think critically of each student is certainly due to each student having different characteristics also between one another. One of the dimensions of student characteristics that need to be considered especially in learning mathematics is cognitive style. Feldhusen \& Goh, as quoted by Emir (2013) stated that "critical thinking is integrated part of the concept of creativity and the program that is directed to develop the critical thinking must absolutely focus on cognitive style among other factors". From these opinions, cognitive style has an important role compared to other factors in developing students 'critical thinking skills, so teachers need to consider students' cognitive styles in carrying out mathematics learning in class.

One cognitive dimension specifically designed in education, special education mathematical styles are distinguished based on psychological differences: field-independent and field-dependent cognitive styles. Students with analytical or field-independent interests, prefer reflexive to the inclined choice of classification and analysis of the visual material provided. If there are things that are not understood, students will immediately ask the requested teacher. They are more critical and flexible. They also appear to be calmer and not confused in reading and think inductively they need to make fewer mistakes. Someone with a field-independent is more flexible than those who depend on the field. 
Cognitively speaking, those who are field-dependent will have difficulty in analyzing problems and finding special difficulties in changing their strategies if the problem demands it, or in using known objects in an unusual way. This is in line with the results of the study of Ilyas (2018) which explains that the learning outcomes of students belonging to the Firld-Independent cognitive style are in the medium category, while the learning outcomes of students belonging to the FieldDependent cognitive style are in the low category.

Based on the description above, that students' mathematical critical thinking skills are still low in solving mathematical problems. This problem is closely related to differences in the ability of each individual to compile and process mathematical information in his mind known as cognitive style, so a deeper study of the problem is needed. Therefore, the authors are interested in analyzing students' critical thinking skills in solving problems in terms of cognitive styles of field independent and field dependent.

\section{METHOD}

The type of this research is a qualitative research with descriptive qualitative methods that are analyzing students 'critical thinking skills in terms of students' cognitive styles. The description of this analysis will explain the students 'critical thinking skills seen from the indicators of students' critical thinking skills according to Ennis previously described. Sampling with Purposive Sampling technique is a sampling technique with certain considerations. Subjects in this study were students of class VIII.9 MTSN 3 Rokan Hulu. The selection of the subject of this study was determined based on the cognitive style test developed by Witkin (1971) and translated by Ulya (2014) and tested for validity and reliability, namely the GEFT (Group Embedded Figures Test). The criteria for determining cognitive styles that have been modified by the author is that if the GEFT score is in the range 0 - 9 then the student has a cognitive field dependent style (FD), whereas if the GEFT score is in the range of 10-15 then the student has an independent field cognitive style (FI). 
Steps to determine the subject are; (1) the results of the GEFT score of students who take the test are ranked from the largest score, (2) students are classified into FD students and FI students with a predetermined range so that 2 groups of students are obtained, (3) one FD student is selected and one FI student as a subject. Data collection techniques in this study were the GEFT test and critical thinking skills test. The results of critical thinking skills tests will then be analyzed which refers to indicators of critical thinking skills that have been determined and adjusted to the GEFT test results that have been obtained. In brief the procedures performed in data analysis are shown in the following figure

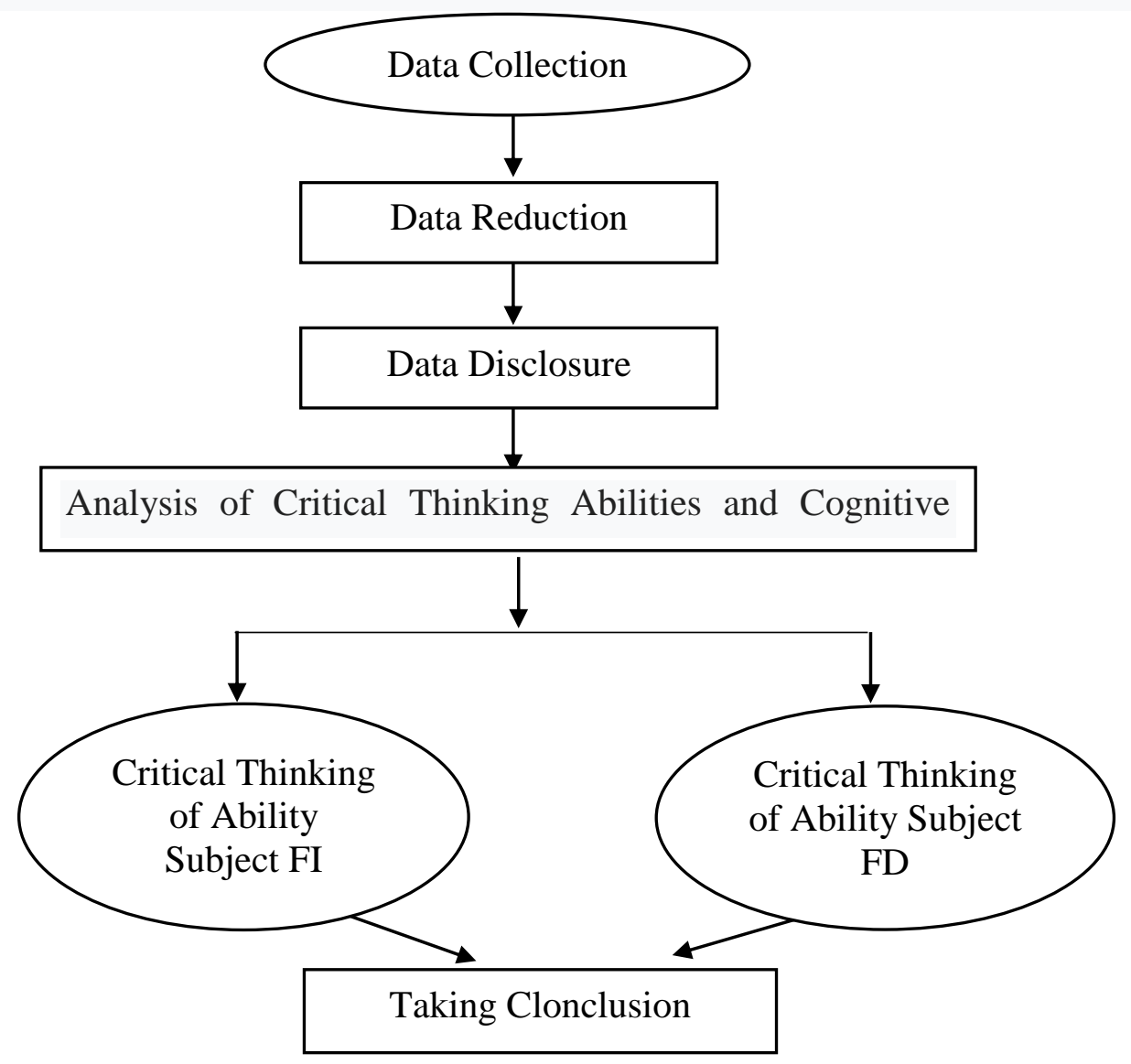

Figure 1. Data Analysis Technique Flowchart

\section{RESULT AND DISCUSSION}

Students' critical thinking skills are analyzed using the indicators presented by Ennis that the researcher has chosen, there are implementing the strategy, giving reasons, and concluding. Determination of the cognitive style of 
eighth grade students of MTSN 3 Rokan Hulu through filling GEFT instruments conducted by students and obtained the following data:

Table 2. Cognitive style of Students in Class VIII.9 MTSN 3 Rokan Hulu

\begin{tabular}{lcc}
\hline \multicolumn{1}{c}{ Cognitive Style } & $\begin{array}{c}\text { Many } \\
\text { Students }\end{array}$ & Percentage (\%) \\
\hline Field Dependent & 13 & 65 \\
\hline Field Independent & 7 & 35 \\
\hline total & 20 & 100 \\
\hline
\end{tabular}

Table 2 shows the number of students in the field dependent cognitive style totaling 13 students (65\%) and the number of independent field cognitive style students totaling 7 students (35\%). After conducting a written test on the ability to think critically in the form of a description of as many as 3 questions, the scoring results obtained from the results of student answers are presented in table 3 as follows:

Table 3. Recapitulation of Students' Critical Thinking Ability in Test Results

\begin{tabular}{cccc}
\hline Indicator & $\begin{array}{c}\text { Question } \\
\text { Number }\end{array}$ & $\begin{array}{c}\text { Percentage of students } \\
\text { who answered true }\end{array}$ & $\begin{array}{c}\text { Percentage of students } \\
\text { who answered false }\end{array}$ \\
\hline $\begin{array}{c}\text { Implement of } \\
\text { Strategies }\end{array}$ & 1 & $15 \%$ & $85 \%$ \\
\hline Give a Reason & 2 & $55 \%$ & $45 \%$ \\
\hline Conclude & 3 & $25 \%$ & $75 \%$ \\
\hline
\end{tabular}

Table 3 shows the results of work on question number 1 with indicators apply the strategy there are $85 \%$ of students who answer incorrectly, this means that almost all students have difficulty in answering question number 1. In problem number 2 with indicators giving reasons there are 55\% of students who have answered right, this means some students have been able to think critically so as not to have difficulty in answering question number 2 . In question number 3 with the indicator concluded there are $75 \%$ of students who answer incorrectly, this means that almost all students have difficulty in answering question number 3

Furthermore, the results of the students' critical thinking skills test are grouped according to the cognitive style groups presented in table 4 below: 
Table 4. Results of Students' Critical Thinking Ability Tests in terms of Cognitive Style

\begin{tabular}{ccc}
\hline $\begin{array}{c}\text { Indicator of Critical } \\
\text { Thinking Ability }\end{array}$ & $\begin{array}{c}\text { Independent Field } \\
\text { Students (FI) }\end{array}$ & $\begin{array}{c}\text { Dependent Field } \\
\text { Students (FD }\end{array}$ \\
\hline Implement Strategies & 3 & - \\
\hline Give a Reason & 6 & 1 \\
\hline Conclude & 4 & 5 \\
\hline
\end{tabular}

Table 4 shows that the indicators applying the strategy only 3 FI subjects who can answer correctly, while all the FD subjects no one can answer correctly. The indicator gives a reason there are subjects who answered correctly namely 6 FI subjects and 5 FD subjects, then the indicator concluded that there were 4 FI subjects who answered correctly and only 1 FD subject who answered correctly.

Written test results and cognitive style test results done by the subject, in general the ability to think critically of each subject in solving problems in terms of cognitive style is described as follows:

Table 5. Results of Data Analysis of Critical Thinking Ability in Resolving Problems of Cognitive Style

\begin{tabular}{ccc}
\hline $\begin{array}{c}\text { Indicator of Critical } \\
\text { Thinking Ability }\end{array}$ & $\begin{array}{c}\text { Field Dependent } \\
\text { Students }(\text { FD) }\end{array}$ & $\begin{array}{c}\text { Field Independent } \\
\text { Students }(\text { FI) }\end{array}$ \\
\hline Implement Strategies & The subject can already & The subject can already
\end{tabular}

(the subject is able to write down the elements explain the situation of decide on the right course given from the problem, the problem in of action to solve the but the strategy or the mathematical form and problem and get a method used by the write the exact solution of the problem) subject in solving the relationship of the problem is not correct, statement of the problem the subject does not think based on the elements long before answering, that must be known, the the subject simply adds strategy / method chosen up all the elements he is appropriate and in knows. accordance with what is 


\begin{tabular}{|c|c|c|}
\hline $\begin{array}{c}\text { Indicator of Critical } \\
\text { Thinking Ability }\end{array}$ & $\begin{array}{l}\text { Field Dependent } \\
\text { Students }(F D)\end{array}$ & $\begin{array}{l}\text { Field Independent } \\
\text { Students (FI) }\end{array}$ \\
\hline & & $\begin{array}{l}\text { known in the problem to } \\
\text { solve the problem. }\end{array}$ \\
\hline $\begin{array}{l}\text { Give a Reason } \\
\text { (the subject is able to } \\
\text { state his argument in } \\
\text { response to a problem } \\
\text { based on what he } \\
\text { understands) }\end{array}$ & $\begin{array}{l}\text { The subject can identify } \\
\text { that the result of the } \\
\text { problem displayed on the } \\
\text { problem is wrong, but } \\
\text { the subject does not } \\
\text { provide an explanation } \\
\text { of the location of the } \\
\text { error as the result of the } \\
\text { problem. Indicates that } \\
\text { in giving the right } \\
\text { answer to the problem, } \\
\text { the subject has } \\
\text { understood and can, but } \\
\text { the ability to give } \\
\text { reasons for an } \\
\text { explanation of the } \\
\text { problem is still lacking. }\end{array}$ & $\begin{array}{l}\text { The subject can identify } \\
\text { and give reasons for a } \\
\text { given problem. Basic } \\
\text { knowledge is needed to } \\
\text { be able to identify the } \\
\text { problems that exist in the } \\
\text { problem. The subject } \\
\text { responds to the problem } \\
\text { given systematically, this } \\
\text { indicates that the subject } \\
\text { uses his thinking ability } \\
\text { before responding to a } \\
\text { problem. }\end{array}$ \\
\hline $\begin{array}{l}\text { Concluding } \\
\text { (the subject is able to } \\
\text { make generalizations } \\
\text { about problems } \\
\text { encountered with the } \\
\text { initial knowledge they } \\
\text { have) }\end{array}$ & $\begin{array}{l}\text { The subject was able to } \\
\text { answer correctly, but the } \\
\text { explanation requested } \\
\text { for the problem was still } \\
\text { lacking. The ability of } \\
\text { the subject to provide } \\
\text { conclusions about the } \\
\text { relationship requested } \\
\text { from the problem is not } \\
\text { good. }\end{array}$ & $\begin{array}{l}\text { The subject answered the } \\
\text { problem correctly and } \\
\text { also the subject's ability } \\
\text { to deduce the relationship } \\
\text { from the given problem } \\
\text { was good, this reflected } \\
\text { the strong basic concept } \\
\text { of the subject regarding } \\
\text { the problem. }\end{array}$ \\
\hline
\end{tabular}


This the following an example of data analysis performed on field independent subjects and field dependent subjects on questions based on indicators of mathematical critical thinking ability:

\section{a) The ability of students to formulate strategies to be taken in solving problems.}

In this indicator a question is tested on question number 1 with the activity asking students to find out whose opinion is right between Faiz and Putri in determining the total number of students using the venn diagram strategy. The following is a visual description of the results of the FI subject and FD subject answers :

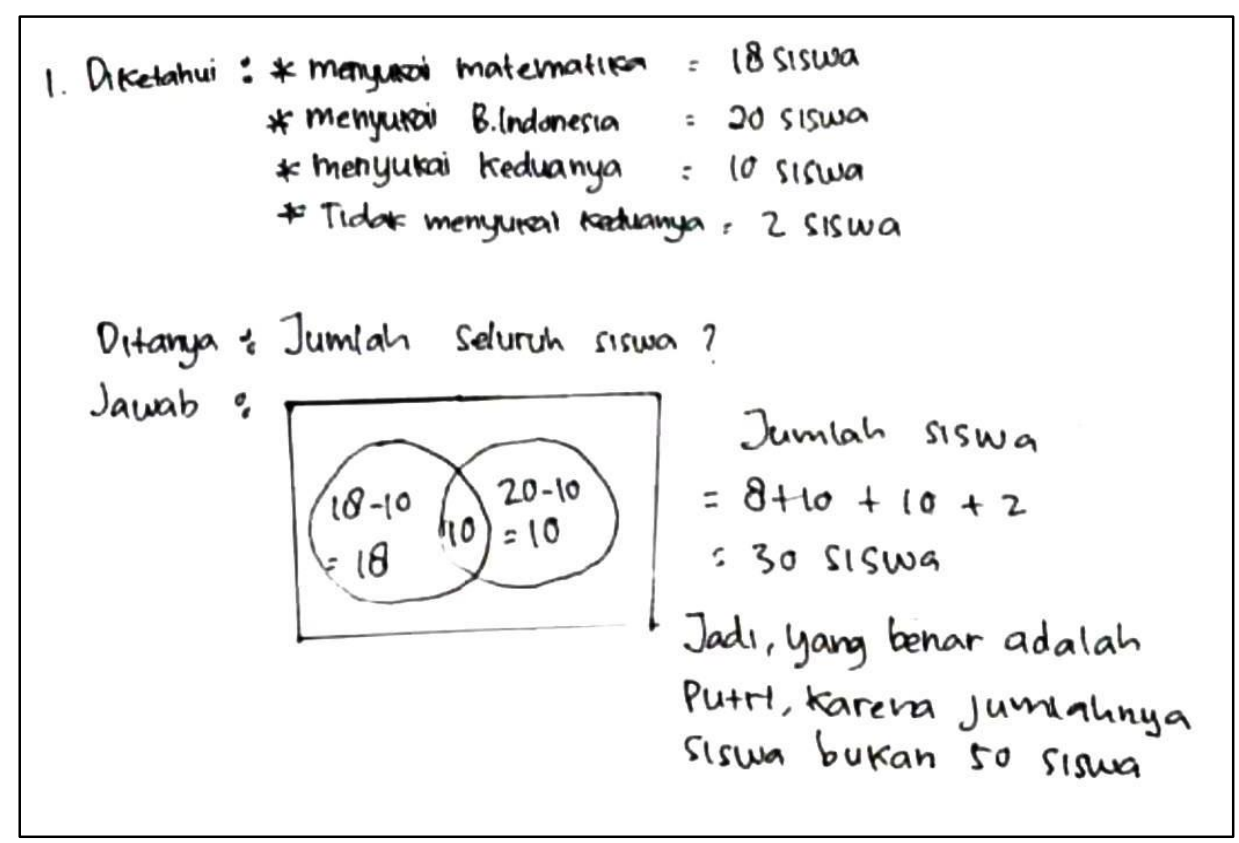

Figure 2. Subject Answer FI

Figure 2 shows that the subject can explain the situation of the problem in mathematical form and is able to identify the exact elements that are known and choose a strategy / method that is in accordance with what is known in the problem to solve it, only when interpreting it into in the venn diagram, the subject is incomplete to write a description of which set likes Mathematics and sets that likes B.Indonesia but the subject already seems to understand how to solve it. This is in accordance with the results of research by Fajari, Kusmayadi, \& Iswahyudi (2013) 
which states that students with independent field cognitive styles are able to determine which method is better for solving a problem. Johnson (2009) also states that there is a relationship between critical thinking and how to solve problems.

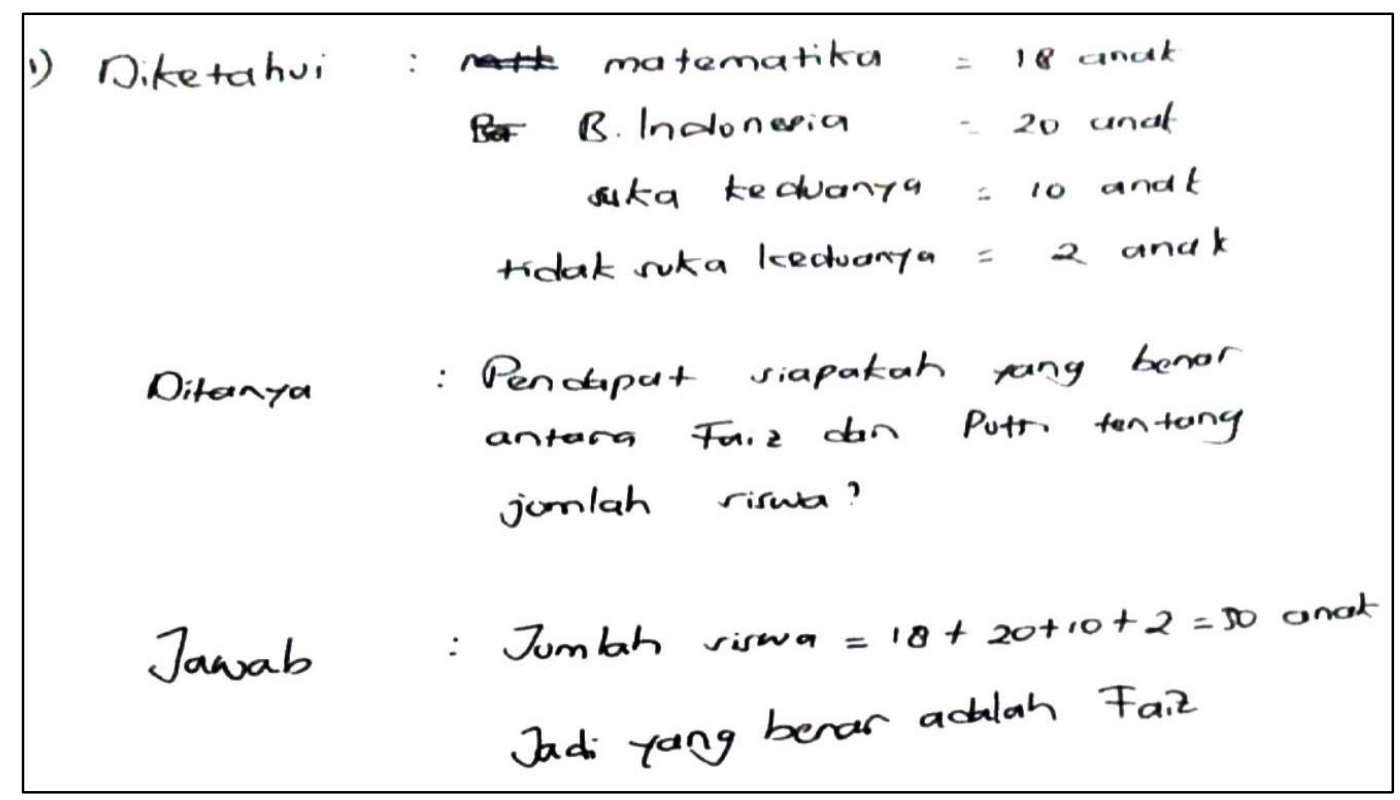

Figure 3. Subject Answer FD

The answers of the subject FD above can be noted that the subject can already write down the elements that are known in the given problem, but the subject is not careful in choosing strategies / ways to solve the problem, it can be seen that the subject just adds all the elements he knows to problems so the answers he gets aren't right. The subject did not think that there was a sliced concept that had to be solved first, namely subtracting those who liked Mathematics or those who liked B.Indonesia with those who liked both, this indicated the subject did not understand the problem well. This is in line with research (Fajari, Kusmayadi, \& Iswahyudi, 2013) which states that students with a field dependent cognitive style at the stage of understanding a problem only tend to accept information as it is without adjusting to the mathematical language that is answering only in the form of verbal sentences. 


\section{b) The ability of students to give reasons for an issue}

In this indicator a question is tested in question number 2 , the instrument used is a question about the multiplication of mixed fractions that have been given a solution and asks the subject to give a reason for the resolution is true or false. The following is an illustration of the answers to the FI subject and the FD subject:

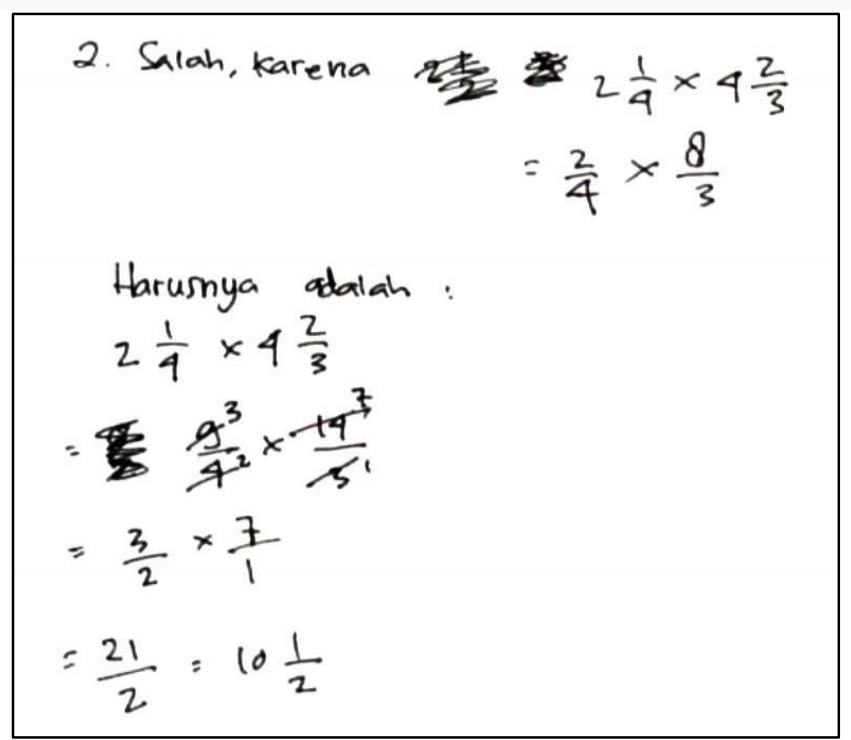

Figure 4. Subject Answer FI

Problem number 2 given to measure students' ability to give reasons for a given problem really requires basic knowledge about mixed fractions. Based on the FI subject's answers in Figure 4, the subject is able to provide reasons for errors contained in working on the existing problems in the problem, and the subject has also been able to provide an explanation or answer with the correct concept of multiplying the mixed fraction numbers. This is in line with the opinion of Herlina \& Dahlia (2018) which states that FI group students are able to state the truth of a statement, analyze the statement, predict, and decide on a problem that has enough evidence. 


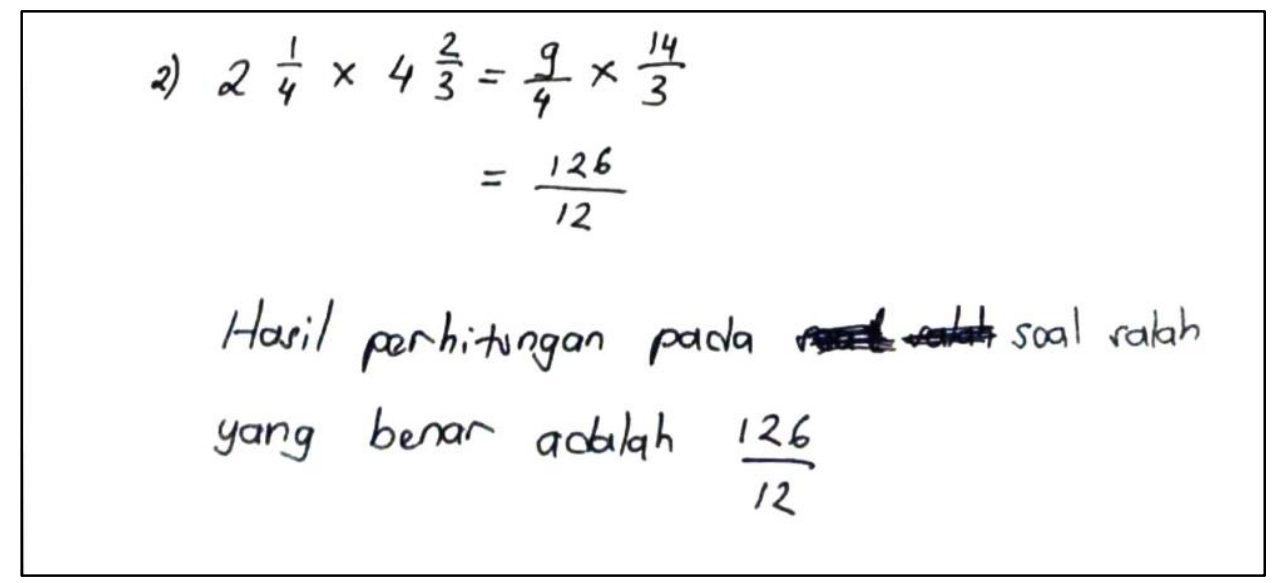

Figure 5. Subject Answer FD

The answer of the subject in Figure 5 above shows that the subject can identify that the workmanship given in the problem is wrong, but the subject does not provide a reason or explanation regarding the location of the workmanship error as requested in the problem. The FD subject understood and was able to solve the problem of multiplication of mixed fractions, but his ability to think of reasons for errors in the work given to the problem was still lacking because he only said at the conclusion that the calculation results on the problem were wrong without giving a reason. Herlina \& Dahlia (2018) also stated in their research that students in the FD category were considered unable to provide simple explanations and were also less able to predict and decide on evidence to tell the truth of a problem statement.

\section{c) The ability of students to make conclusions.}

In this indicator a question will be tested in question number 3 that tests the ability of students to interpret or infer the relationship between the circumference, length, and width of a rectangle. The following is an illustration of the answers to the FI subject and the FD subject: 


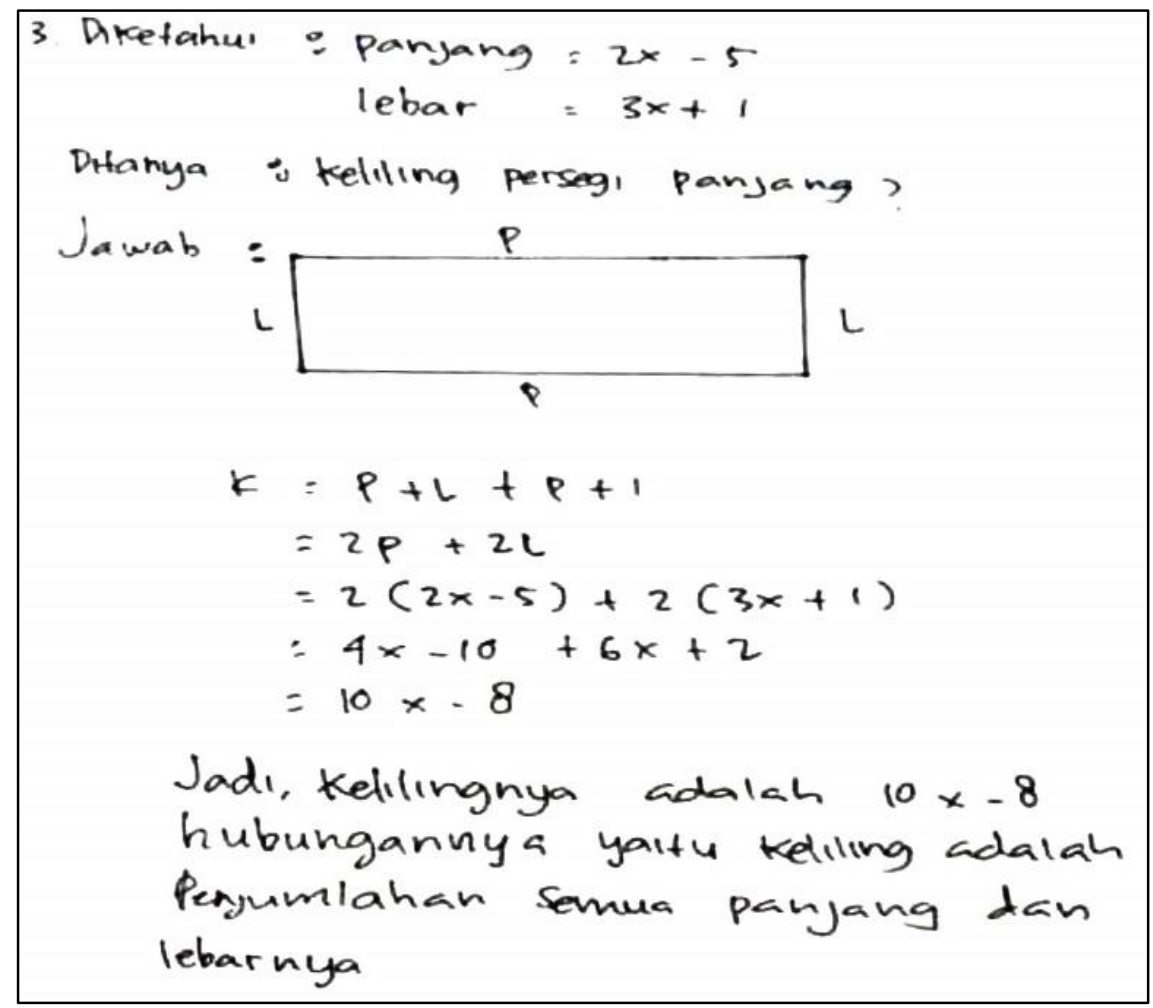

Figure 6. Subject Answer FI

The answer to the subject FI from Figure 6 above can be concluded that the ability of the subject to deduce the relationship between the circumference, length, and width of a rectangle is very good. The subject answered the problem systematically, starting from constructing a rectangular image and writing the concept of the perimeter of the rectangle and solving the subject was also appropriate and in accordance with the concept of finding the circumference of the rectangle. The subject's ability to provide conclusions from solving the problem reflects the strong thinking ability of the subject regarding basic concepts. Hardiyanti, Yani \& Sayu (2019) also stated that students with the FI learning style in working on the critical thinking ability test given were able to reach the inference indicators and other indicators, so that the FI group students were classified as students with high and moderate critical thinking abilities. 


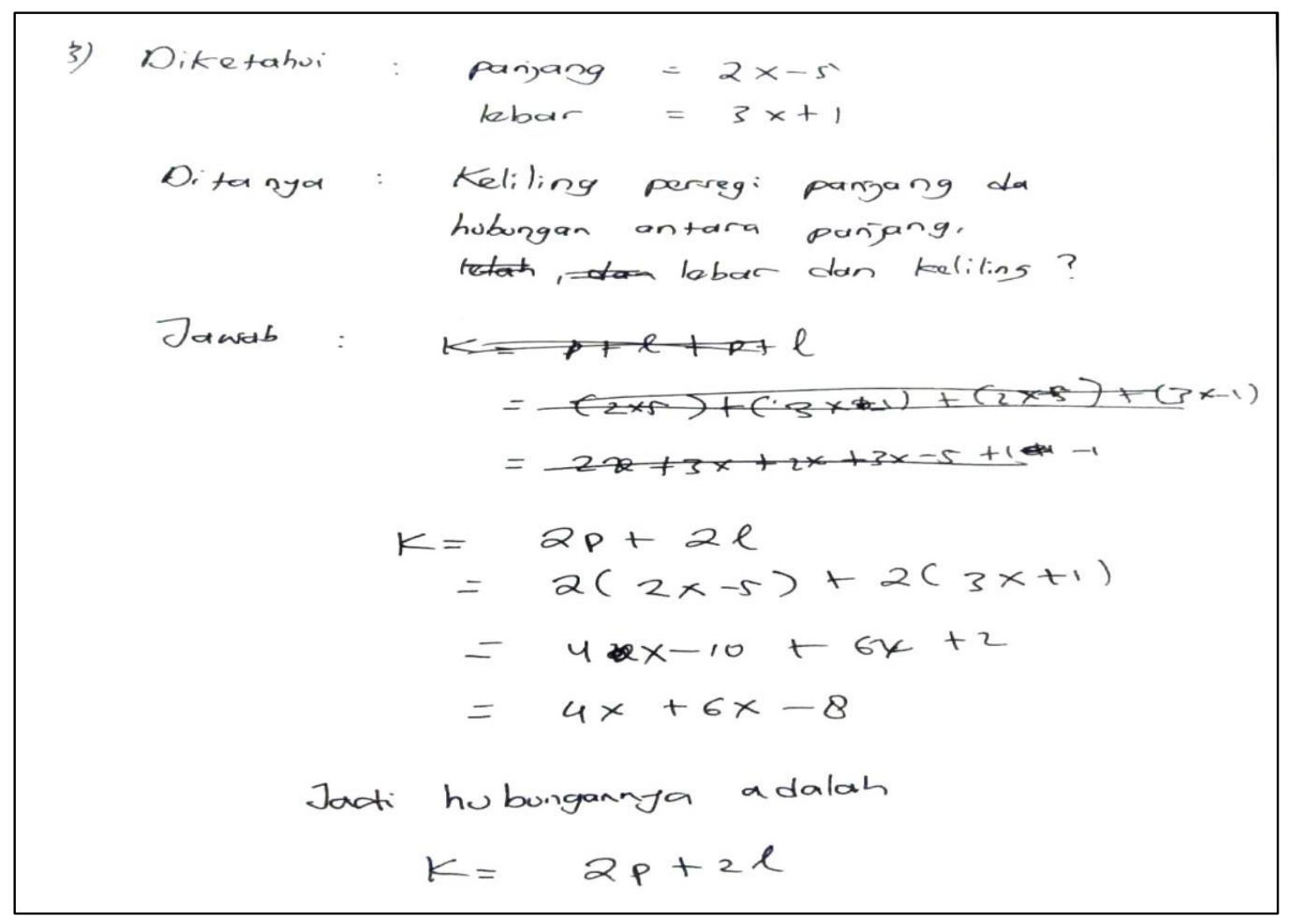

\section{Figure 7. Subject Answer FD}

The answer from the FD subject in Figure 7 shows that the subject in determining the perimeter of the rectangle of the given problem is correct, but the subject's ability to think inferring the relationship between circumference, length, and width as requested in the problem is still not good, the subject only writes the formula of the circumference of a rectangle without clearly interpreting the basic concept of the circumference of the rectangle. This is in line with Hardiyanti, Yani \& Sayu's research (2019) which states that subjects who have an FD learning style have not been able to meet the indicators concluded in working on a given critical thinking ability test, so that the FD subject is said to have low critical thinking abilities.

Based on the analysis of critical thinking skills in terms of the cognitive styles of field dependent and field independent, the findings in this study are that the critical thinking skills of subjects from field independent groups are better than the critical thinking skills of subjects from the field dependent groups. This is in line with research conducted by Ilyas (2018) which states that student learning outcomes 
that are classified as independent field cognitive styles are better than student learning outcomes that are classified as field dependent cognitive styles. In addition, research conducted by Fridanianti (2018) also shows that cognitive style can indeed affect the level of critical thinking of students in solving problems, that is, reflective cognitive style is able to meet all the criteria of critical thinking skills, whereas implusive cognitive style can only meet two criteria out of 6 criteria which is given.

\section{CONCLUSIONS AND RECOMMENDATIONS}

Based on the results and discussion, the following conclusions are obtained:

1) The ability to think critically subjects with field independent cognitive style on indicators applying the subject's strategy can already explain the situation of the problem in mathematical form and write the exact relationship of the question statement based on the elements that must be known, the strategy / method chosen is appropriate and appropriate. In the indicator gives the reason the subject can identify and give reasons for a given problem, the subject responds to the problem given systematically, this indicates that the subject uses the ability to think before responding to a problem and the indicator concludes the subject answers the problem correctly and also the ability of the subject in concluded the relationship of the given problem is good, this reflects a strong basic concept of the subject regarding the problem.

2) The ability to think critically subjects with cognitive style dependent on indicators applying the subject's strategy can already write the elements given from the problem, but the subject is not appropriate in using the strategy or way to solve the problem. In the indicator gives a reason the subject can identify the problem, but the subject does not provide an explanation of the location of the error as a result of the solution to the problem and the indicator concludes the subject is able to answer correctly, but the explanation requested is still lacking. 
3) The ability to think critically subjects with field independent cognitive style is better than the ability to think critically subjects with field dependent cognitive style.

There are differences in the process and results of critical thinking tests between field dependent and field independent subjects in the learning process, so the researcher suggests as an educator to pay attention to the cognitive style of each student in learning, especially in exercising students' critical thinking skills.

\section{REFERENCES}

Chotimah, S., Bernard, M., \& Wulandari, S. M. (2018). Contextual approach using VBA learning media to improve students' mathematical displacement and disposition ability.

Emir, S. (2013). Contribusing of Teacher's Thinking Styles to Critical Thinking Dispositions (Istanbul-Fatih Sample). Educational Sciences: Theory \& Practice. 13(1): 337-347.

Ennis, R. H. (2011). The Nature of Critical Thinking: Sn Outline of Critical Thinking Dispositions and Abilities. Online available at http://faculty.education.illinois.edu/rhennis/documents/TheNatureofCrit icalThinking 51711_000.pdf. Diakses 13-10-2019.

Fajari, A. F. N., Kusmayadi. T. A., Iswahyudi. G. (2013). Profile of Students' Critical Thinking Processes in Contextual Mathematical Problem Solving in Terms of Field Dependent-Independent and Gender Cognitive Style. Journal of Mathematics Learning. Volume 1, No. 6.

Fridanianti, Avinda., dkk. (2018). Analysis of Critical Thinking Ability in Solving Class VII Algebra Questions 2 Steps in Judgment of the Reflective Cognitive and Impulsive Cognitive Styles. Axiom Journal. Volume 9, No. 1, July 2018.

Hardiyanti, A., Yani, A. T., Sayu, S. 2019. Critical Thinking Ability Judging From the Dependent Field and the Independent Field of Triangle and Quadrilateral Material. Untan Journal. Available at https://www.google.com/url?sa=t\&rct=j\&q=\&esrc=s\&source=web\&cd 
$=12 \& \mathrm{cad}=$ rja $\&$ uact $=8 \&$ ved $=2$ ahUKEwj08tmIns7mAhXHXSsKHdwuA rEQFjALegQICXAJ\&url=http\%3A\%2F\%2Fjurnal.untan.ac.id\%2Finde x.php\%2Fjpdpb\%2Farticle\%2Fdownload\%2F37520\%2F75676583990

\&usg=AOvVaw0YC5-ZWk90CRnQjWwWeY45

Herdiman, Indri., and friends. (2018). Mathematical Critical Thinking Ability of Middle School Students on Circle Material. Prisma Journal. Volume VII, No. 1, June 2018.

Herlina, S., Dahlia, A. 2018. Analysis of Mathematical Critical Thinking Ability of Students Prospective teachers in terms of Cognitive Style Based on Independent Field and Field Dependent at Riau Islamic University. Scientific Journal of Mathematics Education, Mathematics and Applied Mathematics (AdMathEdu). Volume 8, No. 1.

Ilyas, Muhammad. (2018). Deskripsi Hasil Belajar Matematika Siswa Pada Materi Bilangan Bulat Ditinjau Dari Gaya Kognitif Field Independent dan Field Dependent. Jurnal Pedagogy. Volume 3, No. 1.

Johnson, Elaine. 2009. Contextual Teaching \& Learning. Bandung: Mizan Media Utama.

Natasia, D., Ariawan, R., Sthephani, A. 2018. The Effect of a Visual Thinking Learning Approach on the Mathematical Critical Thinking Ability of Class VII Students of SMP Negeri 1 Siak Hulu. National Mathematics Education Seminar FKIP UIR, 29-30 August 2018. Available at https://snpm.uir.ac.id

OECD-PISA. (2019). Learing Mathematics for life: A View Perspective from PISA. OECD Publishing

Regulation of the Minister of Education and Culture of the Republic of Indonesia Number 21 of 2016 concerning the Content Standards for Primary and Secondary Education. 2016.

Syahbana, Ali. (2012). Increased Mathematical Critical Thinking Ability of Middle School Students Through Contextual Theaching and Learning (CTL) Approach. Edumatica Journal. Volume 2. Number 1. Pages 45-57.. 
Amini, N. U., Maimunah, dan Roza, Y.2019. Analysis Students' Critical Thinking Skills in Solving Problems... Matematika dan Pembelajaran, 7(2), $\underline{69}$ of 69

Septiana, Restian. (2019). Analysis of Mathematical Critical Thinking Ability of Middle School Students. Journal of Innovative Mathematics Learning (JPMI). Volume 2 No. November 6, 2019.

Sunaryo, Y. (2013). Tasikmalaya, a Problem Based Learning Model to Improve Mathematical Critical and Creative Thinking Ability of High School Students in the City. Doctoral Dissertation: Open University.

Ulya, H. (2014). Analysis of the Ability to Solve Middle School Mathematics Problems in Cognitive Style Students. Thesis. Semarang State University. 